\title{
Analisa Ekonomi Penggantian Pakan Komersial dengan Kombinasi Tepung Daun Mengkudu (Morinda citrifolia $L$ ) dan Tepung Daun Pepaya (Carica papaya L) Pada Pemeliharaan Ayam Pedaging
}

\author{
Damaryanto Widharto ${ }^{1}$ \\ ${ }^{1)}$ Akademi Peternakan Karanganyar (Apeka). Jl. Lawu no. 115, Karanganyar (57716); Telp./Fax. \\ 0271-495212; E-mail : damaryw@ymail.com
}

\begin{abstract}
Abstrak
Tujuan penelitian ini untuk mengetahui tingkat efisiensi penggantian pakan komersial dengan kombinasi tepung daun mengkudu dan tepung daun pepaya pada usaha pemeliharaan ayam pedaging. Materi yang digunakan yaitu 60 ekor day old chick yang dibagi dalam 4 kelompok perlakuan yaitu pemberian pakan komersial tanpa penggantian dengan kombinasi tepung daun mengkudu dan tepung daun pepaya (T-0); penggantian pakan komersial dengan kombinasi Tepung Daun Mengkudu sebanyak 1,5\% dan Tepung Daun Pepaya sebanyak 0,5 $\%$ (T-1); penggantian pakan komersial dengan kombinasi Tepung Daun Mengkudu sebanyak 1,0\% dan Tepung Daun Pepaya sebanyak 1,0\% (T-2); penggantian pakan komersial dengan kombinasi Tepung Daun Mengkudu sebanyak 0,5\% dan Tepung Daun Pepaya sebanyak 1,5\% (T-3). Variabel yang diamati adalah feed conversion, feed cost per gain dan income over feed cost. Hasil penelitian didapatkan feed conversion untuk masing-masing perlakuan yaitu 1,51 (T0), 1,28 (T1), 1,27 (T2) dan 1,26 (T3), feed cost per gain yaitu Rp. 11.994,36,- (T0), Rp. 11.015,38,- (T1), Rp. 10.570,78,- (T2) dan Rp. 10.521,78,- (T3), sedangkan untuk income over feed cost yaitu Rp. 14,705,2,- (T-0), Rp.17.048,8,- (T-1), Rp. 17.252,0,- (T2) dan Rp.17.508,5, (T-3). Hasil analisis menunjukkan bahwa penggantian pakan komersial dengan kombinasi tepung daun mengkudu dan tepung daun pepaya dapat menurunkan nilai konversi pakan, menekan biaya pakan (feed cost per gain) dan memberikan pendapatan yang lebih tinggi. Kesimpulan dari penelitian ini yaitu penggantian pakan komersial dengan kombinasi tepung daun mengkudu dan tepung daun pepaya mampu meningkatkan efisiensi pada usaha pemeliharaan ayam broiler.
\end{abstract}

Kata kunci: Analisis ekonomi, pakan komersial, tepung daun mengkudu, dan tepung daun pepaya.

\begin{abstract}
The purpose of this study was to determine the efficiency level of substitution commercial feed with mengkudu (Morinda citrifolia L) and pepaya (Carica papaya L) leaves flour combination in broiler chickens. The research use 60 day old chick of broilers which were devided into 4 treatments, that is T-0 were given commercial feed without substitution, T-1 were given commercial feed with substitution of leaves flour Morinda citrifolia L. (1.5\%) and Carica papaya L. (0.5\%), T-2 were given commercial feed with substitution of leaves flour Morinda citrifolia L. (1.0\%) and Carica papaya L. (1.0\%) and T-3 were given commercial feed with substitution of leaves flour Morinda citrifolia $L$. (0.5\%) and Carica papaya $L$. (1.5\%). The variables observed feed conversion, feed cost per gain and income over feed cost. The result of the study obtained that the feed conversion was 1,51 (T-0), 2,28 (T-1), 1,27 (T2) and 1,26 (T-3), feed cost per gain Rp. 11.994,36,- (T0), Rp. 11.015,38,- (T1), Rp. 10.570,78,(T2) and Rp. 10.521,78,- (T3), and income over feed cost Rp. 14.705,2,- (T-0), Rp. 17.048, 8, - (T-1), Rp. 17.252,0,- (T2) and Rp.17.508,5,- (T-3). The result of the analysis show an increase in feed conversion efficiency, feed cost efficiency and income over feed cost. Research conclusion is substitution commercial feed with Morinda citrifolia $L$. and Carica papaya $L$. leaves flour combination can increase of efficiency in broiler chickens.
\end{abstract}

Key word: Economic analysis, commercial feed, morinda citrifolia $L$ and carica papaya $L$ leaves flour

\section{PENDAHULUAN}

Pakan merupakan salah satu komponen utama yang harus selalu tersedia dalam usaha pemeliharan unggas, khususnya ayam pedaging. Manajemen pemberian pakan yang akan menentukan berhasil atau tidaknya dalam memberikan keuntungan secara finansial. Hal ini dapat dikarenakan pakan merupakan salah satu faktor penting yang harus diperhatikan dalam usaha peternakan unggas. Zuprizal (2006) menyatakan bahwa biaya pakan merupakan biaya yang cukup besar yaitu bias mencapai 65-70 persen dari total biaya produksi. Oleh karena itu perlu dicari solusi untuk mendapatkan bahan pakan alternatif agar mampu menekan konsumsi 
pakan sehingga dapat mengurangi biaya pakan. Bahan pakan alternatif yang dimungkinkan mampu menekan konsumsi pakan tersebut adalah berasal dari tanaman herbal diantaranya tepung daun mengkudu (Morinda citrifolia). dan tepung daun papaya (Carica papaya).

Tepung daun mengkudu cukup potensial untuk pakan ternak karena kandungan nutrisi cukup tinggi yaitu protein kasar (PK) sebesar $21,63 \%$, dan serat kasar (SK) sebesar 29,38 $\%$ (Nastiti, et al.. 2014). Pada daun mengkudu terkandung protein, zat kapur, zat besi, karoten dan askorbin yang memiliki efek farmakologis yaitu dalam ekstrak kloroform daun mengkudu secara in vitro mempunyai aktivitas anthelmintik, cukup baik melawan cacing ascaris lumbricoides yang ada pada usus sehingga mampu memperlancar dan meningkatkan proses pencernaan (Darusman, 2002). Sedangkan daun pepaya (Carica papaya) mengandung beberapa senyawa yang dapat mempermudah kerja usus dan berguna untuk proses pencernaan (Kamaruddin dan Salim, 2003). Di dalam daun pepaya juga banyak terkandung enzim papain yang memiliki kemampuan untuk membentuk protein baru yaitu plastein dan enzim proteolitik yang dapat meningkatkan efisiensi proses pencernaan sehingga dapat proses absorbs nutrisi dapat otimal. Hasil uji laboratorium menunjukkan bahwa daun pepaya mengandung protein kasar (PK) 20,88\%, kalsium (Ca) 0,99\%, fosphor (P) 0,47\%, dan energy $2912 \mathrm{kkal} / \mathrm{kg}$. Selain itu, daun pepaya juga mengandung $\beta$ karoten yang dapat berfungsi sebagai provitamin A sebesar 18250 dan dapat digunakan sebagai sumber xantophyl alami (Sutama, 2008). Menurut Ardina (2007) pada daun pepaya terkandung enzim papain yang berfungsi sebagai antimikrobial dan alkaloid yang berfungsi sebagai antibakteri. Enzim papain juga memiliki sifat sebagai antimikrobial yang dapat menghambat kerja beberapa mikroorganisme. Komponen aktif $B$ karoten (pro-vitamin A) pada daun pepaya dapat sebagai antioksidan (Sutama, 2008).
Memperhatikan potensi dari tepung daun mengkudu dan tepung daun papaya maka perlu dilakukan kajian dengan penelitian tentang Tinjauan Ekonomi Penggantian Pakan Komersial dengan Kombinasi Tepung Daun Mengkudu dan Tepung Daun Pepaya. Tujuan yang akan dicapai dari penelitian ini yaitu untuk mengetahui tingkat efisiensi usaha pemeliharaan ayam pedaging yang meliputi Feed Conversion, Feed Cost per Gain dan Income Over Feed Cost.

\section{BAHAN DAN METODE}

\subsection{Bahan dan alat}

Bahan yang dipergunakan dalam penelitian ini yaitu :

a. Anak ayam pedaging starin Ross umur 1 hari (Day Old Chick) yang diperoleh dari Poultry Shop di Karanganyar sebanyak 60 ekor dengan rata-rata bobot awal 34,5 gram per ekor.

b. Pakan komersial berupa konsentrat BR-1 produksi PT. Japfa Comfeed Indonesia.

c. Tepung daun mengkudu dan Tepung daun pepaya

Alat yang dipergunakan dalam penelitian ini yaitu :

a. Kandang kelompok ulangan sebanyak 12 unit, dengan ukuran 0,7 $\times 1$ meter

b. Tempat pakan dan minum sebanyak 12 unit

\subsection{Metode}

Metode penelitian yang dilakukan adalah metode eksperimen dengan desain yang digunakan Rancangan Acak Lengkap (RAL). Anak ayam umur 1 hari sebanyak 60 ekor, dibagi secara acak ke dalam 4 perlakuan, dan setiap perlakuan terdiri dari 3 ulangan dengan jumlah ayam masing-masing 5 ekor. Perlakuan dalam penelitian, yaitu:

1. Perlakuan kontrol (T-0), yaitu kelompok ayam yang diberi pakan komersial tanpa penggantian dengan kombinasi tepung daun mengkudu dan tepung daun pepaya.

2. Perlakuan pertama (T-1), yaitu kelompok ayam yang diberi pakan komersial dengan penggantian kombinasi Tepung Daun Mengkudu sebanyak 1,5\% dan Tepung 
daun Pepaya sebanyak 0,5\% dari ransum basal.

3. Perlakuan ke-dua (T-2), yaitu kelompok ayam yang diberi pakan komersial dengan penggantian kombinasi Tepung Daun Mengkudu sebanyak $1 \%$ dan Tepung Daun Pepaya sebanyak $1 \%$ dari ransum basal.

4. Perlakuan ke-tiga (T-3), yaitu kelompok ayam yang diberi pakan komersial dengan penggantian kombinasi Tepung Daun Mengkudu sebanyak $0,5 \%$ dan Tepung Daun Pepaya

\subsection{Variabel Penelitian}

3.1. Sebagai variable control (T-0) adalah pemberian pakan komersial tanpa adanya penggantian dengan kombinasi Tepung Daun Mengkudu dan Tepung Daun Pepaya.

3.2. Sebagai variable independent adalah penggantian pakan komersial dengan kombinasi Tepung Daun Mengkudu dan Tepung Daun Pepaya sebanyak 2\% dari ransum basal.

3.3. Sebagai variable dependent adalah Feed Convertion, Feed Cost per Gain dan Income Over Feed Cost.

\subsection{Analisis Data}

Data yang diperoleh selanjutnya dianalisis statistik menggunakan program SPSS for Windows Release 15.0 dan perbedaan antar perlakuan dilakukan uji lanjut duncant multiple range test (DMRT).

\section{HASIL DAN PEMBAHASAN}

\subsection{Feed Convertion}

Konversi pakan memiliki pengertian sebagai banyaknya pakan yang dibutuhkan untuk menghasilkan pertambahan bobot badan. Tinggi-rendahnya nilai konversi pakan menunjukkan tingkat efisiensi dalam suatu usaha budidaya ternak. Rata-rata nilai konversi pakan dari penggantian pakan komersial dengan kombinasi tepung daun mengkudu (TDM) dan tepung daun papaya (TDP). Rata-rata nilai konversi pakan ayam broiler pada masing-masing perlakuan dari nilai yang paling kecil ke paling besar adalah $\mathrm{T} 3=1,26 ; \mathrm{T} 2=1,27 ; \mathrm{T} 1=1,28 ;$ dan $\mathrm{T} 0=1,51$ (Lampiran 3). . Hasil penelitian ini menunjukkan bahwa pada perlakuan T0 membutuhkan pakan sebanyak $1,51 \mathrm{~kg}$ untuk menghasilkan kenaikan bobot badan sebesar $1 \mathrm{~kg}$, sedangkan untuk T1 membutuhkan pakan sebanyak 1,28 kg, untuk T2 membutuhkan pakan sebanyak $1,27 \mathrm{~kg}$ dan untuk T3 membutuhkan pakan sebanyak 1,26 kg. Hasil ini menjelaskan bahwa penggantian pakan komersial dengan kombinasi tepung daun mengkudu (TDM) dan tepung daun pepaya (TDP) mampu menurunkan nilai korversi pakan. Pengaruh tersebut di atas dikarenakan penggantian pakan komersial dengan kombinasi tepung daun mengkudu (TDM) dan tepung daun pepaya (TDP) mampu menekan konsumsi pakan tetapi dapat meningkatkan pertambahan bobot badan.

Konsumsi pakan pada kelompok perlakuan T1, T2 dan T3 mengalami penurunan dibandingkan dengan perlakuan T0, dan memiliki tingkat pertumbuhan yang lebih baik dibandingkan dengan perlakuan T0 sehingga menghasilkan nilai konversi pakan yang lebih rendah. Dengan kata lain bahwa penggantian pakan komersial dengan kombinasi tepung daun mengkudu (TDM) dan tepung daun pepaya (TDP) memiliki tingkat efisiensi pakan yang lebih baik. Adapun tingkat efisiensi pakan yang dicapai dari masingmasing perlakuan yaitu untuk T1 sebesar 0,23 $\mathrm{kg}(15,33 \%)$; T2 sebesar 0,24 kg (15,89\%) dan T3 $0,25 \mathrm{~kg}(16,56 \%)$ bila dibandingkan dengan perlakuan T0. Hal ini sesuai pendapat Lacy dan Vest, (2004), menyatakan bahwa nilai konversi pakan merupakan suatu ukuran untuk menilai efisiensi dalam penggunaan pakan, semakin rendah konversi pakan maka akan semakin efisien karena semakin sedikit jumlah pakan yang dibutuhkan untuk menghasilkan pertambahan bobot badan dalam jangka waktu tertentu. Mazi (2013) menyatakan bahwa konversi pakan merupakan salah satu standar produksi untuk menilai efisiensi pakan yang dikonsumsi ternak menjadi daging atau sebagai patokan tingkat produktifitas ayam. 


\subsection{Feed Cost per Gain}

Feed cost per gain adalah besarnya biaya pakan yang diperlukan ternak untuk menghasilkan 1 Dapat dijelaskan bahwa untuk menghasilkan 1 kilogram berat badan diperlukan biaya pakan yaitu pada T0 sebesar Rp. 11.994,36,-, sedangkan untuk T1 dibutuhkan biaya pakan sebesar Rp. 11.015,38,-, T2 dibutuhkan biaya pakan sebesar Rp. 10.570,78,- dan biaya pakan T3 sebesar Rp. 10521,78,(Lampiran 4). Hasil ini menunjukkan bahwa penggantian pakan komersial dengan kombinasi tepung daun mengkudu (TDM) dan tepung daun pepaya (TDP) mampu menekan biaya pakan untuk setiap $\mathrm{kg}$ bobot badan. Sedangkan pencapaian tingkat efisiensi yang ditunjukkan dengan sesilih dari feed cost per gain untuk masing-masing perlakuan yaitu selisih T0T1 sebesar Rp. 978,98,-, T0-T2 sebesar Rp. 1.423,58,-, dan T0-T3 sebesar Rp. 1.472,58,-. Perhitungan feed cost per gain dilakukan karena biaya pakan berkisar antara $60-80 \%$ dari biaya total produk (Astutik et al., 2002), sedangkan menurut Prawirokusumo (1994) sit. Widharto dan Risyani (2020) yang menyatakan bahwa biaya pakan memegang peranan penting karena merupakan biaya terbesar dari total biaya usaha dibidang peternakan. Oleh sebab itu, penggunaan pakan yang berkualitas baik dan harga yang relatif murah merupakan suatu kebutuhan untuk mencapai tingkat efisien tertentu.

Selisih yang didapatkan menunjukkan bahwa pada T3 memiliki tingkat efisiensi biaya pakan yang paling tinggi yaitu 12,28\%, diikuti oleh T2 yaitu $11,87 \%$ dan T1 memiliki tingkat efisiensi biaya pakan paling rendah yaitu $8,16 \%$. Hal ini memberikan arti bahwa penggantian pakan komersial dengan kombinasi tepung daun mengkudu (TDM) dan tepung daun pepaya (TDP).sampai dengan level 2 persen mampu meningkatkan efisiensi biaya pakan sebesar 8,16 - 12,28 persen. Terjadinya peningkatan efisiensi biaya pakan tersebut sebagai efek dari penggantian pakan komersial dengan kombinasi tepung daun mengkudu (TDM) dan tepung daun pepaya (TDP).yang memiliki fungsi memperbaiki proses pencernaan sehingga pakan yang dikonsumsi mampu dikonversikan secara maksimal menjadi produksi daging. Hal ini sesuai dengan pendapat Bangun dan Sarwono (2002) bahwa daun mengkudu memiliki kandungan xeronine yang dikenal dapat membantu penyerapan protein. Proses penyerapan protein yang lancar dimungkinkan akan meningkatkan efisiensi pakan dan ternak dapat meningkat pertumbuhan. Wardiny (2006), menyatakan bahwa tepung daun mengkudu mengandung B-karoten, Fe dan Zn yang dapat membuat ayam lebih cepat dewasa kelamin, meningkatkan produksi, menekan konversi pakan dan pertambahan bobot badan meningkat. Pendapat Kamaruddin dan Salim (2003), yang menyatakan bahwa pada daun pepaya terdapat senyawa yang dapat mempermudah kerja usus dan berguna untuk proses pencernaan yaitu enzim papain yang memiliki kemampuan membentuk protein baru (plastein) dan enzim proteolitik yang dapat meningkatkan efisiensi proses pencernaan. Sedangkan menurut Sutama (2008) daun pepaya memiliki komponen aktif $B$ karoten pada yang berfungsi sebagai antioksidan yang mampu memberikan efek kesehatan ternak sehingga dapat memperlancar proses metabolisme. Hamzah (2019) menyatakan bahwa penambahan tepung daun pepaya dapat memperbaiki konsumsi 
pakan, bobot badan dan konversi pakan ayam buras.

\subsection{Income Over feed cost (IOFC)}

Income over feed cost mempunyai pengertian sebagai pendapatan yang merupakan selisih antara penerimaan dari usaha budidaya ayam pedaging dengan biaya pakan. Hal ini sesuai pendapat Mayulu, et al., (2009) dan Siregar (2002) yang menyatakan bahwa Income over feed costs (IOFC) merupakan selisih antara penerimaan dengan biaya pakan. Penerimaan didapatkan dari perkalian antara hasil produksi peternakan dengan harga ayam pada saat itu, sedangkan biaya pakan adalah didapatkan dari jumlah pakan yang dikonsumsi selama pemeliharaan dikalikan dengan harga pakan. Pada usaha budidaya ayam pedaging selalu mengharapkan mendapatkan nilai income over feed cost yang tinggi, karena IOFC merupakan indikator keberhasilan dalam suatu usaha. Menurut Yamin (2008) bahwa Income Over Feed Cost dapat dihitung dengan cara harga penjualan ayam dikurangi dengan biaya pakan yang dihabiskan selama periode pemeliharaan. Sedangkan menurut Prasetiyo (2013) bahwa penerimaan merupakan perkalian antara produksi peternakan atau PBBH dengan harga jual, sedangkan biaya pakan adalah biaya yang dikeluarkan untuk menghasilkan pertambahan bobot badan ternak Analisis biaya pakan (feed cost), Penerimaan (income) dan pendapatan (Income over feed cost) dari hasil penelitian tentang penggantian pakan komersial dengan kombinasi tepung daun mengkudu (TDM) dan tepung daun pepaya (TDP) pada pemeliharaan ayam

Pendapatan tertinggi yang diperoleh dari penggantian pakan komersial dengan kombinasi tepung daun mengkudu (TDM) dan tepung daun pepaya (TDP) sebanyak $2 \%$ dengan komposisi $25 \%$ dan $75 \%$ (T3) sebesar Rp. 17.508,5,-/ekor, diikuti pada penggantian pakan komersial dengan kombinasi tepung daun mengkudu (TDM) dan tepung daun pepaya (TDP) sebanyak $2 \%$ dengan komposisi 50\% dan 50\% (T2) sebesar Rp. 17.252,0,-/ekor dan pada penggantian pakan komersial dengan kombinasi tepung daun mengkudu (TDM) dan tepung daun pepaya (TDP) sebanyak $2 \%$ dengan komposisi $75 \%$ dan $25 \%$ (T1) sebesar Rp. 17.048,8,- dan pendapatan terendah dicapai dari perlakuan tanpa penambahan tepung daun mengkudu dan tepung daun pepaya (T0) yaitu sebesar Rp. 14.705,2,- (Lampiran 5).

Tingkat pendapatan terbesar diperoleh pada perlakuan T3 yaitu $28,58 \%$, diikuti T2 sebesar $17,32 \%$, T1 sebesar $15,94 \%$, bila dibandingkan dengan Pendapatan T0 (Lampiran 8). Hasil ini juga menunjukkan bahwa penggantian pakan komersial dengan tepung daun mengkudu (TDM) dan tepung daun pepaya (TDP) mampu meningkatkan pendapatan. Perhitungan Income over feed cost (IOFC) dilakukan dengan tujuan untuk mengetahui nilai ekonomis dari usaha pemeliharaan ayam broiler. Priyanti et al., (2012) menyatakan bahwa income over feed cost (IOFC) adalah konsep untuk mengetahui analisis usaha sebagai indikator awal kegiatan pemeliharaan ayam broiler. Hasil analisa pendapatan tersebut menunjukkan bahwa penggantian sebagian pakan komersial dengan kombinasi tepung daun mengkudu (TDM) dan tepung daun pepaya (TDP) dapat meningkatkan pendapatan (IOFC) dalam pemeliharaan ayam pedaging.

\section{SIMPULAN}

Memperhatikan hasil penelitian dan uraian pembahasan maka dapat disimpulkan sebagai berikut : 


\section{Agrisaintifika \\ Jurnal Ilmu-Ilmu Pertanian \\ Vol. 5, No. 2, 2021}

Harinta \& Arianti., 2021

1. Penggantian pakan komersial dengan kombinasi tepung daun mengkudu dan tepung daun pepaya mampu menekan konversi pakan, menurunkan biaya pakan dan meningkatkan pendapatan.

2. Penggantian pakan komersial dengan kombinasi tepung daun mengkudu dan tepung daun pepaya mampu meningkatkan efisiensi pakan, biaya pakan dan pendapatan pada usaha pemeliharaan ayam broiler.

3. Penggantian pakan komersial dengan kombinasi tepung daun mengkudu 75persen dan tepung daun pepaya 25 persen (T3) memiliki tingkat pendapatan yang tertinggi, diikuti kombinasi tepung daun mengkudu 50 persen dan tepung daun pepaya 50 persen (T2) dan terendah pada kombinasi tepung daun mengkudu 25 persen dan tepung daun pepaya 75 persen (T1).

\section{DAFTAR PUSTAKA}

Ardina, Y. 2007. Development of Antiacne Gel Formulation and Minimum Inhibitory Concentration Jurnal Sain Peternakan Indonesia Vol 9 No 1. Januari-Juni \begin{tabular}{l|lll}
2014 & 48 & ISSN $1978-3000$
\end{tabular} Determination from Carica Papaya Leaves Extract (Carica papaya A Linn.). http://digilib.itb.ac.id/gdl.php.

Astutik, S. I. B., M. Arifin, dan W. S. Dilaga. 2002. Respon sapi PO berbasis pakan jerami padi terhadap berbagai formula "urea molasses blok". Seminar Nasional Teknologi PeternakandanVeteriner. Fakultas Peternakan, Universitas Diponegoro, Semarang.

Bangun, A.P. dan B. Sarwono. 2002. Sehat dengan ramuan tradisional, khasiat dan manfaat mengkudu. Jakarta : Agromedia Pustaka.

Darusman, L.K. 2002. Mengkudu (Morinda Citrifolia) : kandungan bahan aktif dan efek farmokologisnya. Lamongan : Makalah disampaikan pada pertemuan koordinasi dalam rangka pengembangan agribisnis tanam obat, 25-26 September 2002.

Febriani, M., 2010. Penggunaan Khamir Laut Sebagai Biokatalisator Dalam Pembuatan Silase Daun Mengkudu (Morinda Citrifolia) Sebagai Salah Satu Bahan Pakan Alternatif Untuk Pakan Ikan. Prosiding Forum Inovasi Teknologi Akuakultur. http://www.sidik.litbang.kkp.go.id/index. php

Hamzah, M.H. (2019). Pengaruh Pemberian Tepung Daun Pepaya Dalam Ransum Pakan Ayam Buras Terhadap Bobot Ayam Buras, Skripsi. Fapet. Universitas Nusantara PGRI. Kediri.

Kamaruddin, M. dan Salim. 2003. Pengaruh Pemberian Air Perasan Daun Pepaya Pada Ayam : Respon Patofisilogik Hepar. Jurnal Sain Veteriner. 20 (1): $37-43$.

Lacy, M. dan L. R. Veast. 2004. Improving Feed Conversion in Broiler : A Guide for Growers. Spinger Science and Businsess Media Inc. New York.

Mayulu, H, B. Suryanto, Sunarso, M. Christiyanto, F. I. Ballo and Refa'i. 2009. Feasibility of Complete feed Based on Ammonitiated Fermented Rice Straw Utilization on the Beef Cattle Farming. J. I. Tropic. Anim. Agri. 34: $74-78$

Mazi, K., Supartini, N., dan Darmawan, H. 2013. Tingkat Konsumsi, Konversi dan Income Over Feed Cost pada Pakan Ayam Kampung dengan Penambahan Enzim Papain. Thesis. Program Studi Peternakan, Fak. Pertanian. Univ. Tribhuwana Tunggadewi. Malang.

Nastiti RA, Hermana W \& Mutia R. 2014. Penggunaan dedak gandum kasar (wheatbran) sebagai pengganti jagung dengan kombinasi tepung daun mengkudu (Morinda citrifolia) untuk menghasilkan telur puyuh sehat rendah kolesterol dan kaya vitamin A. Buletin Makanan Ternak 101(1):1-12. 
Agrisaintifika

Jurnal Ilmu-Ilmu Pertanian

Vol. 5, No. 2, 2021

Harinta \& Arianti., 2021

Priyanti, A., I. G. A. P. Mahendri, F. Cahyadi and R. A. Cramb. 2012. Income over feed cost for small-to medium-scale beef cattle fattening operation in East Java.

Prasetiyo, A. B. 2013. Partisipasi pelaksanaan program sarjana membangun desa dalam pengembangan sapi potong di Kabupaten Bantul Daerah Istimewa Yogyakarta. Thesis. Fakultas Peternakan, UniversitasGadjahMada, Yogyakarta.

Siregar, E. 2002. Pengaruh Pemberian Tepung Buah Tanjung (Mimusopselengi L.) Dalam RansumTerhadap Performans Kecil Lokal Umur 8 -16 minggu.

Sutama, I. N. S. 2008. Daun Pepaya dalam Ransum Menurunkan Kolesterol pada

Serum dan Telur Ayam. Jurnal Veteriner 9 (3) : 152-156

Wardiny, 2006. Kandungan vitamin A, C dan kolesterol telur ayam yang diberi mengkudu (Morinda citrifolia) dalam ransum. Thesis. Bogor (ID): Institut Pertanian Bogor.

Widharto, D., dan Risyani, L., 2020. Penggantian Pakan Komersial dengan Kombinasi Tepung Daun Mengkudu dan Tepung Daun Pepaya Terhadap Performans Ayam Pedaging. Agrisaintifika Jurnal IImu-IImu Pertanian. Vol. 5, No. 1, 2021

Zuprizal, 2006. Nutrisi unggas. Handout.Jurusan Nutrisi dan Makanan Ternak.Fakultas Peternakan. UGM Yogyakarta. 
Lampiran 1. Nilai gizi bahan pakan penelitian

\begin{tabular}{|l|r|r|r|}
\hline \multirow{2}{*}{ Zat gizi } & \multicolumn{3}{|c|}{ Bahan pakan } \\
\cline { 2 - 4 } & Konsentrat ${ }^{1)}$ & $\begin{array}{c}\text { Tepung daun } \\
\text { mengkudu }{ }^{2)}\end{array}$ & $\begin{array}{c}\text { Tepung daun } \\
\text { pepaya }{ }^{3}\end{array}$ \\
\cline { 2 - 4 } & \multicolumn{3}{|c|}{} \\
\hline 1. Bahan Kering (BK) & 88,00 & 89,95 & 87,37 \\
\hline 2. Protein Kasar (PK) & 21,00 & 15,92 & 16,77 \\
\hline 3. Serat Kasar (SK) & 4,00 & 22,12 & 16,28 \\
\hline
\end{tabular}

Sumber : PT. Japfa Comfeed Indonesia ${ }^{1)}$

Febriani (2010) ${ }^{2)}$

Widyaningrum (2012) ${ }^{3)}$

Lampiran 2. Komposisi dan perhitungan nilai gizi pakan penelitian

\begin{tabular}{|l|c|c|c|c|}
\hline \multirow{2}{*}{ Bahan pakan } & \multicolumn{4}{|c|}{ Komposisi pakan penelitian (\%) } \\
\cline { 2 - 5 } & $\mathrm{T}-0$ & $\mathrm{~T}-1$ & $\mathrm{~T}-2$ & $\mathrm{~T}-3$ \\
\hline 1. Konsentrat & 100 & 98 & 98 & 98 \\
\hline 2. Tepung daun mengkudu & - & 0,5 & 1 & 1,5 \\
\hline 3. Tepung daun pepaya & - & 1,5 & 1 & 0,5 \\
\hline \multicolumn{1}{|c}{ Kandungan gizi pakan } & $\mathrm{T}-0$ & $\mathrm{~T}-1$ & $\mathrm{~T}-2$ & $\mathrm{~T}-3$ \\
\hline 1. Bahan Kering (BK; \%) & 88,00 & 88,00 & 88,01 & 88,03 \\
\hline 2. Protein Kasar (PK; \%) & 21,00 & 20,91 & 20,91 & 20,90 \\
\hline 3. Serat Kasar (SK; \%) & 4,00 & 4,27 & 4,30 & 4,33 \\
\hline
\end{tabular}

Lampiran 3. Rata-Rata Konversi Pakan

\begin{tabular}{lrrrr}
\hline \multirow{2}{*}{ Parameter } & \multicolumn{4}{c}{ Perlakuan } \\
\cline { 2 - 5 } & \multicolumn{1}{c}{ T0 } & \multicolumn{1}{c}{ T1 } & \multicolumn{1}{c}{ T3 } \\
\hline 1. Konsumsi (g/ekor/hari) & 67,41 & 61,81 & 60,00 & 64,38 \\
2. Pertambahan bobot badan (g/ekor/hari) & 44,69 & 48,69 & 47,39 & 51,08 \\
3. Konversi pakan & 1,51 & 1,28 & 1,27 & 1,26 \\
\hline
\end{tabular}

Lampiran 4. Rata-Rata Konversi Pakan

\begin{tabular}{lcccc}
\hline \multirow{2}{*}{ Parameter } & \multicolumn{4}{c}{ Perlakuan } \\
\cline { 2 - 5 } & $\mathrm{T} 0$ & $\mathrm{~T} 1$ & $\mathrm{~T} 2$ & $\mathrm{~T}$ \\
\hline 1. Harga pakan (Rp./kg) & 7.960 & 8.625 & 8.350 & 8.325 \\
2. Konversi pakan & 1,51 & 1,28 & 1,27 & 1,26 \\
3. Feed cost per gain (Rp./kg) & $11.994,36,-$ & $11.015,38,-$ & $10.570,78,-$ & $10.521,78,-$ \\
\hline
\end{tabular}

Keterangan : 1) harga TDM = Rp. $30.000 / \mathrm{kg}$ dan 2) harga TDP = Rp. $25.000 / \mathrm{kg}$ 
Harinta \& Arianti., 2021

Lampiran 5. Data biaya pakan (feed cost) masing-masing perlakuan

\begin{tabular}{lcccc}
\hline Indikator Analisis & T0 & T1 & T2 & \\
1. Konsumsi (kg/ekor) & 1,88 & 1,73 & 1,68 & 1,82 \\
2. Harga pakan (Rp./kg) & $7.960,-$ & $8.625,-$ & $8.350,-$ & 8.325 \\
\hline 3. Biaya pakan (Rp./ekor ) & $14.964,8,-$ & $14.921,3$ & $14.028,0,-$ & $15.151,5,-$ \\
\hline \multicolumn{4}{l}{ Keterangan : Data harga bahan pakan diambil pada saat penelitian. }
\end{tabular}

Lampiran 6. Data penerimaan (income) masing-masing perlakuan

\begin{tabular}{lcccc}
\hline \multicolumn{1}{c}{ Indikator Analisis } & T0 & T1 & T2 & \\
\hline $\begin{array}{l}\text { 1. Bobot badan (kg/bobot badan) } \\
\begin{array}{l}\text { 2. Harga ayam (Rp./kg bobot } \\
\text { badan) }\end{array}\end{array}$ & 1,29 & 1,39 & 1,36 & 1,42 \\
\hline 3. Penerimaan (Rp./ekor) & $23.000,-$ & $23.000,-$ & $23.000,-$ & $23.000,-$ \\
\hline
\end{tabular}

Keterangan : Data harga ayam diambil pada saat penelitian.

Lampiran 7. Data Income Over Feed Cost masing-masing perlakuan

\begin{tabular}{lcccc}
\hline Indikator Analisis & T0 & T1 & T2 & \\
\hline 1. Biaya Pakan (Rp./ekor) & $14.964,8,-$ & $14.921,3$ & $14.028,0,-$ & $15.151,5,-$ \\
2. Penerimaan (Rp./ekor) & $29.670,0,-$ & $31.870,0,-$ & $31.280,0,-$ & $32.660,0,-$ \\
\hline 3. Pendapatan; IOFC (Rp./ekor) & $14.705,2,-$ & $17.048,8,-$ & $17.252,0,-$ & $17.508,5,-$ \\
\hline
\end{tabular}

Keterangan : Data harga bahan pakan dan ayam diambil pada saat penelitian.

Lampiran 8. Rata-rata Selisih Pendapatan T-1, T-2 dan T-3 dengan T-0

\begin{tabular}{ccc}
\hline Perlakuan & Selisih & Persentase \\
\hline T0 - T1 & Rp. 2.343,6,- / ekor & $15,94 \%$ \\
T0 - T2 & Rp. 2.546,8,- / ekor & $17,32 \%$ \\
T0 - T3 & Rp. 4.203,0,- / ekor & $28,58 \%$ \\
\hline
\end{tabular}

